\title{
成人歯科集団検診と組み合わせて行う歯周病予防プログラム に関する研究
}

\author{
第 1 報 CPITN を用いた予防プログラムの検討 \\ 菅谷 勉 向中野 浩* 渡部亘貴 加藤 熙 \\ 北海道大学歯学部歯科保存学第 2 講座 \\ (主任：加藤 熙教授) \\ *ミュー歯科クリニック \\ (札幌市，開業） \\ (平成 8 年 8 月 8 日受付)
}

A Study of the Preventive Program for Periodontal Disease in Association with

\author{
Adult Mass Dental Examination \\ I Examination of the Preventive Program According to CPITN \\ Tsutomu Sugaya, Yutaka Mukainakano*, Nobuki Watanabe and Hiroshi Kato \\ Department of Periodontology and Endodontology, Hokkaido University School of Dentistry \\ Kita 13, Nishi 7, Kita-ku, Sapporo 060, Japan \\ (Chief : Prof. Hiroshi Kato) \\ ${ }^{*}$ Myu Dental Clinic \\ 1-15-1-20 Tsukisamu-higashi, Toyohira-ku, Sapporo 062, Japan
}

The purpose of this study was to establish a preventive program for periodontal disease associated with adult mass dental examination. Periodontal status was surveyed by using CPITN among 900 employees (mean age : 41.2) in Hokkaido. A questionnaire was given to 411 of the subjects. The questionnaire included smoking habits, personal awareness of periodontal disease, history of periodontal treatments and habits of oral hygiene. The influence of these factors, P1.I. and C. I. on CPITN was analyzed by using Hayashi's Quantification to determine the essential factors of the preventive program and to evaluate the possibility of selecting a high risk group from the questionnaire, who may require intensive preventive measures. The following results were obtained. The prevalence of periodontal disease was $84.5 \%$.
$82.2 \%$ of subjects showed a CPITN of more than 2 . Therefore it was suggested that oral hygiene instruction alone was ineffective and that scaling was neccesary for the prevention of periodontal disease. A significant correlation was found between CPITN and oral hygiene index, while smoking habits and other factors had little influence. Selection of a high risk group from the quesionnaire was not possible. These results suggested that a preventive program of periodontal disease combined with adult mass dental examination should be performed in all subjects irrespective of other factors (ie., awareness of periodontal disease and oral hygiene habits) and preventive measures (ie., oral hygiene instruction, scaling and recommendation to a dental office) should be taken according to periodontal status.

Key words : CPITN, Preventive program of periodontal disease, Adult mass dental examination, High risk group, Hayashi's Quantification

要旨：成人歯科集団検診に組み合わせて行う適切な歯周病予防プログラムを作成する目的で，まず北海道の某 
企業の勤労者 900 名（平均 41.2 歳）を対象に，CPITN により歯周病の罹患状態を評価した。その中の 411 名 に対し, 喫煙習慣, 歯周病の自覚, 歯周病治療経験, 口腔清掃習慣などの予防上検討する必要があると思われる 因子をアンケート調查した。これらの因子と P1.I., C.I. が CPITN に及ぼす影響を，林式数量化理論により分析 して, プログラムに組み込む必要のある因子を調べるとともに，重点的に予防処置を行う危険集団を，アンケー 卜調査により選別することの可能性を検討した。その結果, 対象者の $84.5 \%$ が歯周病に罹患しており, CPITN 2 以上が $82.2 \%$ であり，歯周病予防処置は口腔清掃指導だけでは不十分でスケーリングが必要と思われた。ま た, CPITN と口腔衛生状態とは強い相関がみられたが, 喫煙習慣などの因子の影響は小さく, 予防処置として プログラムに組み込む必要性は少ないと思われた。さらに，アンケート調査から危険集団を選別する方法は効果 が低いと考えられた。以上の結果から，成人歯科集団検診と組み合わせて行う歯周病予防処置は，歯周病の自覚 や口腔清掃習慣などの因子を考慮することなく対象者全員に歯周病の検診を行い, 各対象者の歯周病進行状態に 応じて口腔清掃指導やスケーリング，歯科医院受診勧告をそれぞれ単独または組み合わせて行うプログラムが適 切と思われた。

索引用語：CPITN，歯周病予防プログラム，成人歯科集団検診，危険集団，林式数量化理論

\section{緒言}

歯周病はわが国の抜歯原因の約半数を占めてお $\eta^{1)}$, とくに成人期以後の歯牙喪失の最大原因となっ ている。これは歯周病が自覚症状に乏しいため放置さ れやすいことが原因の一つと考えられる。さらに歯周 病は重症化すればするほど治療が長期化, 複雑化して 困難になるため, 歯周病を積極的に予防し, 早期に発 見治療することが重要視されてきている。しかしなが ら,わが国においては歯科保健活動として, 一次予 防, 二次予防 ${ }^{21}$ の観点から計画されプログラムされた 歯周病対策はほとんど行われておらず，ごく一部で成 人歯科集団検診時に口腔清掃指導が行われている3 8) のが現状である。

最近わが国でも各地域で成人歯科集団検診が行われ るようになってきており，この成人歯科集団検診に適 切な歯周病予防プログラムを組み入れることは, 実施 しやすくしかも効果が得られやすい方法ではないかと 思われる。そこで, 歯科集団検診時に各対象者の歯周 病䍜患状態と歯周病に影響すると考えられる喫煙など の因子を調べ，それに応じた適切な予防処置を行うこ とが有効と考えられる。さらに, 歯周病の罹患率の高 さを考慮すると, 予防処置を必要とする対象者は多大 な数になると考えられ，アンケート調査により歯周病 の危険集団を選別できれば，効率的に予防処置を行う ことが可能と思われる。

そこで, 本研究は成人歯科集団検診時に歯周病の罹 患状態を調査するとともに，喫煙などの因子が予防処 置を行う上でどの程度歯周病に影響を及ぼしているの か, さらに歯科医院への通院状況や歯周病の自覚, 口 腔清掃習慣などについてアンケート調查を行い, 歯周 病の危険集団の選別の可能性について分析し, 集団検
診と組み合わせて行う歯周病予防プログラムを試作し た。

\section{材料および方法}

対象者は, 北海道の企業 14 社の勤労者 900 名（男 性 669 名，女性 231 名，年齢 16～68 歳，平均 41.2 歳)とした。

被験歯は，まず全歯牙を対象に齨蝕と喪失状態を調 查した後, 歯周病については被験歯を左右上下顎第 1 大臼歯, 右上顎中切歯, 左下顎中切歯の 6 歯とした。 被験歯が欠損している場合は，隣接する第 2 大臼歯お よび反対側の中切歯を被験歯とした。診査項目は, plaque index (P1.I.) $)^{9)}$, probing depth, calculus index (C.I.) ${ }^{10)}$, gingival index (G.I. $)^{9)}$ と , $\mathrm{CPITN}^{11)}$ により歯周病の罹患状態を評価した。

診査は臨床経験 9 年以上の歯科医師 2 名が行ない, 被験歯 6 歯の平均值を CPITN-Ave とし，6歯の最大 值をCPITN-Max とした。診査結果は Macintosh Quadra $800^{\circledR}$ (Apple Computer, USA) に Excel $4.0^{\circledR}$ (Microsoft, USA) を用いて入力し, Stat View ${ }^{\circledR}$ (Abacus Concepts, Inc. USA) により統計処 理を行った。

次に，対象者の中から任意に 411 名を選び，歯周病 の罹患状態と予防処置を行う上で検討する必要がある と考えられる因子との関係を分析するために，年齢， 性別, 喫煙習慣の有無, 歯周病の自覚の有無, 一日の ブラッシング回数, 一回のブラッシング時間, 過去 2 年以内の歯科治療経験, 口腔清掃指導やスケーリン グ，歯周外科手術などの歯周病治療経験についてアン ケート調査を行い, これらの因子および Pl.I. と C.I. とが, 各対象者の CPITN-Maxに及ぼす影響を解析 した。 


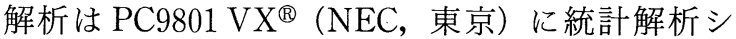
リーズ（林式数量化理論とクラスター分析） ${ }^{\circledR}$ (社会情 報サービス社, 東京）を用いて，目的変数を CPITN-Max $=0$ と 1 以上の 2 群として林式数量化理 論II類 ${ }^{12)}$ により行った。

\section{結果}

年代別の，喪失歯数, CPITN-Ave, Pl.I., C.I. を 表 1 に示した。一人平均賈失歯数は 24 歳以下が 0.47 歯で, 年歯が増加するにつれ多くなり，55～68 歳で は6.29歯であった。CPITN-Aveは 24 歳以下が 0.49, 55〜68 歳では 1.61 で, 年齢の増加とともに歯 周病の悪化がみられた。P1.I. と C.I. は 24 歳以下がそ れぞれ 0.68 と 0.32 で, 55〜68歳が 1.06 と 1.05 で あり, 年齢が増加するにつれ口腔衛生状態が悪化する 傾向がみられた。P1.I. とCPITN-Ave との相関は $\mathrm{R}=0.67 （ \mathrm{p}<0.0001$ ，Spearmann 順位相関 $)$, C.I. とCPITN-Ave との相関は $\mathrm{R}=0.86 （ \mathrm{p}<0.0001$, Spearmann 順位相関）で相関がみられ，口腔衛生状 態と歯周病の進行程度は強く関連していた。
年代別の CPITN-Max の分布を図1に示した。年 齢の増加とともに code 0 が減少し, code 3,4 が増加 しており，経年的に重度の歯周病罹患歯が多くなるこ とが認められた。対象者全体では，CPITN-Max 1 以 上が $84.5 \%$ を占めており，ほとんどの対象者が歯周 病に罹患していることが認められた。その内訳をみる と, CPITN-Max 1 は全体の 2.3\% で, CPITN-Max 2 が $47.5 \%$ と半数近くを占めていた。

歯周病予防を行う上で検討する必要があると思われ た因子の年代別アンケート調査結果を表 2 に示した。 年齢の増加にともない歯周病の自覚や歯周病治療の経 験は増加する傾向がみられたが，他の項目は年代に よって大きな差はみられなかった。喫煙習慣「あり」 は 1 本以上/日，「なし」は 0 本/日であり，喫煙者の 平均本数は $20.7 \pm 10.5$ 本/日であった。さらにこれら の因子および P1.I., C.I. と CPITN-Max との関係を, 数量化理論II類により分析した結果を表 3 に示した。 P1.I., C.I., はレンジ，偏相関係数ともに大きく，歯 周病の罹患状態に強く関与していたが，他の因子はこ れらに比ベレンジ，偏相関係数ともに小さく関連性が 低かった。なお，分析精度の指標である判別的中率は

表 1 年代別歯周病罹患状態 (平均值 \pm S.D.)

\begin{tabular}{cccccc}
\hline 年代(歳) & 人数 & 喪失歯数 & CPITN-Ave & PI.I. & C.I. \\
\hline $16 \sim 24$ & 165 & $0.47 \pm 1.31$ & $0.49 \pm 0.56$ & $0.68 \pm 0.68$ & $0.32 \pm 0.42$ \\
$25 \sim 34$ & 129 & $1.15 \pm 2.04$ & $0.60 \pm 0.61$ & $0.61 \pm 0.47$ & $0.40 \pm 0.49$ \\
$35 \sim 44$ & 161 & $2.66 \pm 2.46$ & $0.98 \pm 0.90$ & $0.82 \pm 0.49$ & $0.67 \pm 0.67$ \\
$45 \sim 54$ & 294 & $3.46 \pm 4.18$ & $1.33 \pm 0.95$ & $0.91 \pm 0.47$ & $0.88 \pm 0.72$ \\
$55 \sim 68$ & 151 & $6.29 \pm 6.73$ & $1.61 \pm 1.03$ & $1.06 \pm 0.54$ & $1.05 \pm 0.72$ \\
\hline 合計 & 900 & $2.92 \pm 4.34$ & $1.05 \pm 0.94$ & $0.83 \pm 0.55$ & $0.70 \pm 0.69$ \\
\hline
\end{tabular}

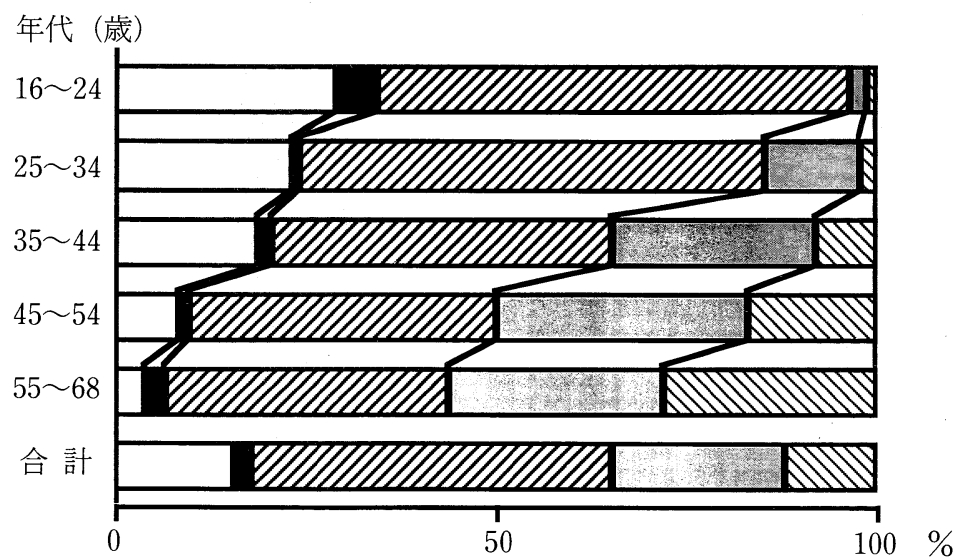

Code $0, \square$ Code $1, \mathbb{Z}$ Code $2, \square$ Code $3, \mathrm{MIN}$ Code 4 ,

図 1 年代別 CPITN-Max の分布状態 
表 2 歯周病予防の上で関連すると思われる因子の年代別アンケート調査結果（\%）

\begin{tabular}{|c|c|c|c|c|c|c|c|c|c|c|}
\hline \multirow{2}{*}{ 年代(歳) } & \multirow{2}{*}{$\begin{array}{l}\text { 喫煙習慣 } \\
\text { ありなし }\end{array}$} & \multirow{2}{*}{$\begin{array}{l}\text { 歯周病の自覚 } \\
\text { あり なし }\end{array}$} & \multicolumn{2}{|c|}{1 日のブラッシング回数 } & \multirow{2}{*}{ 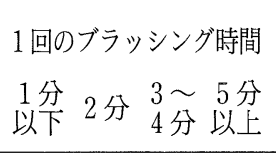 } & \multirow{2}{*}{$\begin{array}{c}\text { 過去 } 2 \text { 年以内の } \\
\text { 歯科治療経験 } \\
\text { あり なし }\end{array}$} & \multirow{2}{*}{$\begin{array}{l}\text { 口腔清掃 } \\
\text { 指導経験 } \\
\text { ありなし }\end{array}$} & \multirow{2}{*}{$\begin{array}{l}\text { スケーリ } \\
\text { ング経験 } \\
\text { ありなし }\end{array}$} & \multicolumn{2}{|c|}{$\begin{array}{l}\text { 歯周外科 } \\
\text { 手術経験 }\end{array}$} \\
\hline & & & 0 回 & 1 回 2 回 $\begin{array}{l}3 \text { 回 } \\
\text { 以上 }\end{array}$ & & & & & あり & なし \\
\hline $16 \sim 24$ & 39.160 .9 & 16.467 .4 & 0 & 22.262 .215 .6 & $\begin{array}{llll}3.6 & 26.1 & 47.1 & 26.1\end{array}$ & 16.865 .2 & 14.184 .7 & 10.996 .2 & 1.1 & 10.7 \\
\hline $25 \sim 34$ & 49.450 .6 & 29.661 .7 & 0 & $\begin{array}{lll}15.4 & 83.3 & 1.3\end{array}$ & 16.024 .727 .225 .9 & 7.455 .6 & 16.055 .6 & 18.579 .0 & 1.2 & 95.1 \\
\hline $35 \sim 44$ & 33.863 .6 & 27.358 .4 & 0 & $39.151 .6 \quad 9.4$ & $\begin{array}{llll}11.7 & 18.2 & 29.9 & 16.9\end{array}$ & 18.233 .8 & 14.358 .4 & 24.763 .6 & 3.9 & 88.3 \\
\hline $45 \sim 54$ & 56.043 .0 & 31.049 .0 & 0 & $\begin{array}{lll}32.3 & 57.0 & 10.8\end{array}$ & 26.019 .027 .029 .0 & 26.040 .0 & 26.044 .0 & 35.054 .0 & 8.0 & 82.0 \\
\hline $55 \sim 68$ & 59.052 .5 & 39.341 .0 & 0 & $\begin{array}{lll}54.7 & 39.6 & 5.7\end{array}$ & $\begin{array}{llll}13.1 & 23.0 & 31.1 & 16.4\end{array}$ & 18.044 .3 & 27.937 .7 & 49.244 .3 & 4.9 & 85.2 \\
\hline 合計 & 47.253 .8 & 24.656 .0 & 0 & $30.7 \quad 60.3 \quad 9.0$ & 14.422 .131 .623 .6 & 16.548 .2 & 19.549 .4 & 26.565 .9 & 3.9 & 88.8 \\
\hline
\end{tabular}

98.0\%，相関比は 0.86 であり，分析精度はきわめて 高かった。

\section{考 察}

歯周病は広く国民に蔓延している疾患であり，その 予防が重要と考えられるが, 適切な歯周病予防プログ ラムについてはほとんど検討されていない。そこで, 成人歯科集団検診に組み合わせて歯周病の予防処置を 行えば，実施しやすくしかも効果が得られやすいと考 え，成人歯科集団検診時に行う効果的な歯周病予防プ ログラムを作成する目的で，まず疫学的調查を行って 歯周病の罹患状態や進行状態を調べた。

対象者は, 札幌市内と近郊に存在する企業の勤労者 で, 今回の調査結果を北海道の歯科疾患実態調査 ${ }^{13)}$ と 比較すると, 本調査の対象者は残存歯数が多く, 齲蝕 は少なく, CPITNも低い傾向が認められた。これ は, 本調査では無歯顎者が 900 名中わずか 3 名であ り, 無歯顎者が少なかったこと, および本調査は札幌 とその近郊の都市部の勤労者を対象としているのに対 し, 北海道歯科疾患実態調査は北海道全域に対象を求 めているため, 地域による口腔健康意識の違いなどが 原因と考えられる。

今回, 歯周病の罹患状態はCPITN-Ave と CPITN-Maxの2つの指標を用いて評価した。 CPITN を歯周病の進行程度を示す指標として用いる 場合には，より多くの被験部位の平均值を用いる方が 実体を把握できると考えられる。そこで, 今回は被験 歯 6 部位の平均值である CPITN-Ave を歯周病の進 行度を示す指標として用いた。その結果, CPITNAve は年齢の増加とともに高くなっており, 増齢に したがって歯周病が増悪することが示された。さら に, Pl.I., C.I. と CPITN-Ave との相関が高く, 口腔 衛生状態が強く影響していることが確認された。

歯周病の予防，早期治療を行うにあたって，どのよ
うな予防プログラムが適切であるかを検討するには， 各対象者の最も重症な部位を基準とする必要があると 考えられる。そこで予防プログラムを検討するにあ たっては, 被験歯 6 歯の最大值である CPITN-Max を用いた。その結果, CPITN-Maxが 0 の者は, 全 対象者の $15.5 \%$ であり, 残り $84.5 \%$ の対象者は歯周 病に罹患していた。さらにその進行状態をみると, 増 齢とともに重症度が増加していた。一方, WHOが口 腔清掃指導のみで対応できるとしている CPITN$\operatorname{Max} 1$ の者は，いずれの年代に扔いても $5.5 \%$ 以下 ときわめて少なく, 予防プログラムとしてロ腔清掃指 導のみを行ったのでは, 十分な効果は期待できないと 考えられた。口腔清掃指導とスケーリングを必要とす ると考えられている CPITN-Max 2 の者は, 対象者 の $36.9 \sim 61.8 \%$ を占めており, 今回の調査から成人 の歯周病予防プログラムには口腔清掃指導に加えてス ケーリングを組み込むことが必要と考えられた。しか しながら, 歯周病の罹患率の高さを考慮すると, 集団 検診時に必要と判定された者全員に十分な口腔清掃指 導と徹底的なスケーリングを行うことは，多大な時間 と費用を要すると考えられる。

そこで，歯周病に影響するという報告 ${ }^{14 \sim 25) か ゙ あ る ~}$ 喫煙，1日のブラッシング回数と時間, 歯周病の自 覚, 歯周治療経験などについてアンケート調查するこ とにより，歯周病の危険集団を選別し，この集団に対 し重点的に予防処置を行うプログラムが効果的ではな いかと考えた。しかしながら，これらの因子が P1.I. やC.I. などによって評価判定される口腔衛生状態に 比較して，歯周病罹患状態にどの程度強く関与してい るかは明らかにされてない。しかも, これらの因子は 相互に関連しあっていると考えられる。そこで, 多変 量解析の一つで定性分析が可能な林式数量化理論 II 類 を用いて比較検討を行った。その結果，これらの因子 が歯周病に関与する程度は, PI.I. や C.I. に比較する と,きわめて低い值を示した。したがって, 現在わが 
表 3 CPITN-Max と歯周病に関連すると考えられる 因子の林式数量化理論 II類による分析結果

目的変数を CPITN $-\mathrm{Max}=0$ ( 63 人) と CPITN $-\mathrm{Max} \geqq$ 1 (348人)の 2 群とした。カテゴリースコアーの負は CPITN-Max を上げ，正は下げる要因となり，レンジと 偏相関計数が目的変数への影響力を示す。

\begin{tabular}{|c|c|c|c|c|c|}
\hline 説明変数 & カテゴリー & 人数 & $\begin{array}{l}\text { カテゴリー } \\
\text { スコアー }\end{array}$ & レンジ & $\begin{array}{l}\text { 偏相関 } \\
\text { 係数 }\end{array}$ \\
\hline 性別 & $\begin{array}{l}\text { 男性 } \\
\text { 女性 }\end{array}$ & $\begin{array}{l}297 \\
114\end{array}$ & $\begin{array}{l}-0.007 \\
-0.017\end{array}$ & 0.024 & 0.084 \\
\hline 年齢 & $\begin{array}{l}16 \sim 24 \\
25 \sim 34 \\
35 \sim 44 \\
45 \sim 54 \\
55 \sim 63\end{array}$ & $\begin{array}{r}92 \\
81 \\
77 \\
101 \\
60\end{array}$ & $\begin{array}{r}-0.073 \\
0.062 \\
0.015 \\
-0.039 \\
0.049\end{array}$ & 0.135 & 0.424 \\
\hline 喫煙習慣 & $\begin{array}{l}\text { あり } \\
\text { なし }\end{array}$ & $\begin{array}{l}191 \\
214\end{array}$ & $\begin{array}{r}0.041 \\
-0.041\end{array}$ & 0.082 & 0.372 \\
\hline 歯周病の自覚 & $\begin{array}{l}\text { あり } \\
\text { なし }\end{array}$ & $\begin{array}{l}106 \\
236\end{array}$ & $\begin{array}{l}-0.019 \\
-0.010\end{array}$ & 0.029 & 0.127 \\
\hline $\begin{array}{l}1 \text { 日のブラッシ } \\
\text { ング回数 }\end{array}$ & $\begin{array}{l}1 \text { 回 } \\
2 \text { 回 } \\
3 \text { 回以上 }\end{array}$ & $\begin{array}{r}121 \\
232 \\
35\end{array}$ & $\begin{array}{r}-0.018 \\
-0.001 \\
0.049\end{array}$ & 0.067 & 0.162 \\
\hline $\begin{array}{l}1 \text { 回のブラッシ } \\
\text { ング時間 }\end{array}$ & $\begin{array}{l}1 \text { 分以下 } \\
2 \text { 分 } \\
3 \sim 4 \text { 分 } \\
5 \text { 分以上 }\end{array}$ & $\begin{array}{r}54 \\
85 \\
149 \\
99\end{array}$ & $\begin{array}{r}-0.036 \\
0.003 \\
0.015 \\
-0.015\end{array}$ & 0.051 & 0.168 \\
\hline $\begin{array}{l}\text { 過去 } 2 \text { 年以内 } \\
\text { の歯科治療 }\end{array}$ & $\begin{array}{l}\text { あり } \\
\text { なし }\end{array}$ & $\begin{array}{r}63 \\
187\end{array}$ & $\begin{array}{r}0.043 \\
-0.014\end{array}$ & 0.056 & 0.218 \\
\hline $\begin{array}{l}\text { 口腔清掃指導 } \\
\text { 経験 }\end{array}$ & $\begin{array}{l}\text { あり } \\
\text { なし }\end{array}$ & $\begin{array}{r}80 \\
203\end{array}$ & $\begin{array}{r}0.038 \\
-0.004\end{array}$ & 0.041 & 0.084 \\
\hline $\begin{array}{l}\text { スケーリング } \\
\text { 経験 }\end{array}$ & $\begin{array}{l}\text { あり } \\
\text { なし }\end{array}$ & $\begin{array}{l}109 \\
271\end{array}$ & $\begin{array}{r}0.023 \\
-0.007\end{array}$ & 0.030 & 0.101 \\
\hline $\begin{array}{l}\text { 歯周外科手術 } \\
\text { 経験 }\end{array}$ & $\begin{array}{l}\text { あり } \\
\text { なし }\end{array}$ & $\begin{array}{r}16 \\
364\end{array}$ & $\begin{array}{r}-0.028 \\
0.002\end{array}$ & 0.030 & 0.053 \\
\hline P1.I & $\begin{array}{c}0 \\
0.1 \sim 0.5 \\
0.6 \sim 1.0 \\
1.1 \sim 1.5 \\
1.6 \sim\end{array}$ & $\begin{array}{r}25 \\
118 \\
181 \\
54 \\
33\end{array}$ & $\begin{array}{r}-0.184 \\
-0.039 \\
0.030 \\
0.045 \\
-0.450\end{array}$ & 0.634 & 0.572 \\
\hline C.I. & $\begin{array}{c}0 \\
0.1 \sim 0.5 \\
0.6 \sim 1.0 \\
1.1 \sim 1.5 \\
1.6 \sim\end{array}$ & $\begin{array}{r}77 \\
183 \\
57 \\
31 \\
63\end{array}$ & $\begin{array}{r}-0.259 \\
0.033 \\
0.065 \\
0.082 \\
0.067\end{array}$ & 0.341 & 0.755 \\
\hline
\end{tabular}

国における成人の歯科集団検診に組み合わせて行う歯 周病予防プログラムで，アンケート調査により危険集 団を選別して，それらの者だけ重点的に予防処置を 行うことは意義が低いと考えられた。さらに喫煙習慣 を有する対象者を禁煙させることは，現在の我々の歯 周病予防プログラムとしては大きな効果を期待できな いと考えられた。喫煙が歯周病に大きな影響を及ぼす という報告は多く，本研究はこれらの報告 ${ }^{14,16 ~ 25)}$ と異
なる結果となった。これは, 喫煙本数や喫煙年数など を詳細に検討していないことも理由の一つとして考え られるが, 歯周病の判定基準や統計処理法の違いが大 きな原因と考えられる。すなわち，これらの報告では 歯周病の判定基準をポケットの深さやアタッチメント ロス, 歯槽骨の吸収程度などとしているが, 本研究で 用いた CPITN 1 以上という判定基準で検討された報 告はみられない。また，他の研究では統計処理法とし てオッズ比を用いているものが多い。そこで本研究の データーを「喫煙者と非喫煙者」「CPITN が 0 と 4 以上」に分類してオッズ比を算出したところ， 2.5 と なり喫煙は歯周病に影響が強いと考えることも可能で あった。しかし，これはプラークや歯石など他の因子 の影響を考慮していないため, 多変量解析法である林 式数量化理論によりこれらの因子との比較を行った結 果, 喫煙の影響はプラークや歯石と比較するときわめ て小さかった。したがって, 本研究と他の多くの報告 とで喫煙の影響が異なった評価になったのは，主に歯 周病の判定基準と統計処理方法が異なっていることが 原因と考えられる。しかし，喫煙は歯周病に対する防

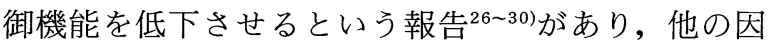
子を含めて今後さらに詳細な検討が必要と思われる。

以上の結果から，わが国における成人の歯周病予防 プログラムとしては，まず，年齢や性別，歯周病の自 覚, ブラッシング習慣, 喫煙習慣, 歯科治療経験など に関係なく, 成人全員に歯周病の検診を行い, 各対象 者の歯周病罹患状態に基づいて歯周病予防処置を行う ことが適切と考えられた。予防処置の内容はWHO の指針を参考にし, CPITN-Max $=0$ が予防処置な し。CPITN-Max =1 が口腔清掃指導。CPITN $\mathrm{Max}=2$ が口腔清掃指導とスケーリング。CPITN $\mathrm{Max}=3,4$ が口腔清掃指導とスケーリングに加え, 歯科医院への受診勧告を行うものとした。こUゾログ ラムを実施した場合に，どの程度の効果をもたらすか はきわめて重要であり，実際に実施して検討を加え， 改善していく必要があると考えている。すなわち CPITN-Max $=0$ の者に対して一次予防として口腔清 掃指導を積極的に行うべきかどうか, CPITN-Max 3 や 4 の者に対して口腔清掃指導とスケーリングに加え て歯科医院の受診勧告を行うことがどの程度効果的か などについて詳しく検討し，わが国の歯周病の予防プ ログラムを確立していく必要がある。

本研究の一部は平成 5 年度文部省科学研究費総合 $\mathrm{A}$ （課 題番号 05304045）の補助を受けて行われた。 


\section{謝辞}

本研究にご協力いただきました雪印乳業健康保険組合歯 科衛生士, 佐藤道子女史, および本学歯科保存学第二講座 教室員各位に深く感謝致します。

\section{文献}

1）厚生省医務局歯科衛生課：平成 5 年度歯科疾患実態 調查報告書, 1993 .

2) Leavell, H.R. and Clark, E.G. : Prevention medicine for the doctor in his community, 2 nd ed. McGraw-Hill, New York, 7-39, 1958.

3）平岩 弘，鶴見真由美，森田 学，坂田真理子，岸 本悦央, 渡邊達夫：百貨店従業員への刷掃指導効果 -1 年後の経過観察一。 日歯周誌, $28: 670-680$, 1986.

4）鶴見真由美，森田 学，平岩 弘，坂田真理子，恵 谷潤三，岡崎眞奈美，小泉和浩，正村眞佐雄，今井 兼武，岸本悦央，渡邊達夫：歯科検診と同時に実施 した刷掃指導の効果について. 岡山歯誌，6，81-86, 1987.

5）市橋 透，熊谷典子，興水正樹，松村輝男，長島 暲，千田 彰，石井拓男，榊原悠紀田郎：名古屋市 内某事業所における歯科保健活動. 第 1 報 唾液潜 血試験および CPITN による歯科保健活動の追跡調 査. 口腔衛生会誌, $41 ： 175-183,1991$.

6）市橋 透，熊谷典子，興水正樹，松村輝男，千田 彰，石井拓男，榊原悠紀田郎：名古屋市内某事業所 における歯科保健活動．第 2 報 従業員の口腔内状 況と歯科保健活動について。口腔衛生会誌，41： 184-191, 1991.

7）木村年秀, 岸本悦央, 森田 学, 石川 昭, 友實 毅, 渡邊達夫：地域における刷掃指導効果 -1 年後 の経過観察一。腔衛生会誌, 41：307-313, 1991.

8）吉田幸恵，小川由紀子，畠中能子，河野綾美，新庄 文明：事業所勤務者に対する個別刷掃指導の喪失歯 に与える効果. 口腔衛生会誌, 42：170-175, 1992.

9) Silness, J. and Löe, H. : Periodontal disease in pregnancy. II Correlation between oral hygiene and periodontal condition. Acta. Odont. Scand.. $22: 121-135,1964$.

10) Löe, H. and Silness, J. : Periodontal disease in pregnancy. I. Prevalence and severity. Acta. Odontol. Scand., $21:$ 533-551, 1963.

11) Ainamo, J., Barmes, D., Beagrie, G., Cutress, T., Martin, J. and Infirri, J.S. : Development of the world health organization community periodontal index of treatment needs. Int. Dent. J., $32: 281$ 291, 1983.

12）林知己夫：数量化の方法，東洋経済新報社, 1975 .

13）北海道保険環境部：北海道歯科疾患実態調查報告
書, 1993.

14) Ismail, A.I., Burt, B.A. and Ekllund, S.A. : Epidemiologic patterns of smoking and periodontal disease on the United States. J.A.D.A., $106: 617-621,1983$.

15）小西浩二, 楠 憲治, 岩本義史, 渡邊達夫, 中村 亮, 辻川次郎, 藤田雄三, 小川洋子, 松村輝男 : 成 人集団における歯科保健活動 第 1 報 歯磨き習慣 と CPITNによる歯周病の評価. 口腔衛生会誌, 37 :677-687, 1987.

16) Bergstrom, J. and Eliasson, S. : Cigarette smoking and alveolar bone height in subjects with a high standard of oral hygiene. J. Clin. Periodontol., $14: 466-469,1987$.

17) Bergstrom, J. : Cigarette smoking as risk factor in chronic periodontal disease. Comm. Dent. Oral Epidemiol., 17 : 245-271, 1989.

18) Goultschin, J., SganCohen, H.D., Donchin, M., Brayer, L. and Soskolne, W.A. : Association of smoking with periodontal treatment needs. J. Periodontol., 61:364-367, 1990.

19) Haber, J. and Kent, R.L. : Cigarette smoking in a periodontal practice. J. Periodontol., 63:100-106, 1992.

20）埴岡隆, 田中宗雄, 玉川裕夫, 需石聰： CPITN を指標とした歯周組織の健康状態と喫煙習 慣との関連性について。日歯周誌, 35：347-352, 1993.

21) Haber, J., Wattles, J., Crowley, M., Mandell, R., Joshipura, K. and Kent, R.L. : Evidence for cigarette smoking as a major risk factor for periodontitis. J. Periodontol., 64 : 16-23, 1993.

22) Stoltenberg, J.L., Osborn, J.B., Pihlstrom, B.L., Herzberg, M.C., Aeppli, D.M., Wolff, L.F. and Fischer, G.E. : Association between cigarette smoking, bacterial pathogens, and periodontal status. J. Periodontol., 64 : 1225-1230, 1994.

23) Grossi, S.G., Zambon, J.J., Ho, A.W., Koch, G., Dunford, R.G., Machtei, E.E., Norderyd, O.M. and Genco, R.J. : Assessment of risk for periodontal disease. I Risk indicators for attachment loss. J. Periodontol., 65 :260-267, 1994.

24) Brown, L.F., Beck, J.D. and Rozier, R.G. : Incidence of attachment loss in community-dwelling older adults. J. Periodontol., 65 : 316-323, 1994.

25) Grossi, S.G., Genco, R.J., Machtei, E.E., Ho, A.W., Koch, G., Dunford, R.G., Zambon, J.J. and Hausmann, E. : Assessment of risk for periodontal disease. II Risk indicators for alveolar bone loss. J. Periodontol., 66 : 23-29, 1995.

26) Eichel, B. and Shahrik, H.A. : Tobacco smoke toxicity : Loss of human leukocyte function and 
fluid cell metabolism. Science, $166: 1424-1428$, 1977.

27) Kenney, E.G., Kraal, J.H., Saxe, S.R. and Jones, J. : The effect of cigarette smoke on human oral polymorphonuclear leukocytes. J. Periodont., Res., 12 : 227-234, 1977.

28) Hedin, C.A., Ronquist, G. and Forsberg, O. : Cyclic nucleotide content in gingival tissue of smokers and non-smokers. J. Periodont. Res., $16: 337-343,1981$.

\section{連絡先：}

北海道大学歯学部歯科保存学第 2 講座

厂 060 札幌市北区北 13 条西 7 丁目
29）埴岡 隆，岩倉功子，零石 聰：ヒト歯肉へモグロ ビン量と酸素飽和度に及ぼす喫煙の影響一妿煙前後 の比較. 口腔衛生会誌, 41：735-737, 1991.

30) MacFarlane, G.D., Herzberg, M.C., Wolff, L.F. and Hardie, N.A. : Refractory periodontitis associated with abnormal polymorphonuclear leukocyte phagocytosis and cigarette smoking. J. Periodontol., 63 : 908-913, 1992. 